$\xi=$

\title{
Evaluation of phytochemical and nutritional potential of Talinum triangulare (Jacq) leaf, stem and root on human health
}

\author{
C.V. Ilodibia ${ }^{1 *}$, N. A. Igboabuchi ${ }^{2}$ \\ ${ }^{1}$ Department of Botany, Nnamdi Azikiwe University, P. M. B 5025, Awka, Anambra State, Nigeria \\ ${ }^{2}$ Department of Biology, Nwafor Orizu College of Education Nsugbe, Anambra State, Nigeria \\ *Corresponding author E-mail:Chinyereokafor206@yahoo.com
}

\begin{abstract}
Phytochemical and nutritional potentials of various parts (leaf, stem and root) of Talinum triangulare were evaluated using standard techniques. Analysis of Variance (ANOVA) was employed in data analysis. All the parts of the species were found to contain nutrient compositions in varying levels. Dry matter and carbohydrate were highest in the stem $(91.69 \pm 0.12$ and $68.66 \pm 0.01)$ respectively. Moisture, ash content and crude fibre were highest in the root $(9.78 \pm 0.04,17.53 \pm 0.11$ and $15.32 \pm 0.03)$ respectively while ether extract and crude protein were highest in the leaf $(1.09 \pm 0.01$ and $17.72 \pm 0.17)$ respectively. The results showed also varying quantities of the phytochemicals in the leaf, stem and root with some parts lacking some of the phytochemicals. The leaf contained the highest percentage of all the phytochemical investigated alkaloid, flavonoid, tannin, sterol, Terpenoid, phenol and saponin $(0.47 \pm 0.01,0.26 \pm 0.00,0.36 \pm 0.07$, $0.03 \pm 0.01,0.42 \pm 0.02,0.02 \pm 0.01$ and $0.68 \pm 0.05$ respectively. The root lacked sterol and phenol while stem lacked only phenol. The leaf, stem and root lacked cyanogenic glycoside. The results have indicated that these parts of the Talinum triangulare investigated are very nutritious and possessed bioactive compounds that could be extracted for the manufacture of new drug, food supplements and also be used in ethnomedicine for the treatment of diseases.
\end{abstract}

Keywords: Bioactive Compound; Nutritional; Phytochemical; Talinum Triangulare.

\section{Introduction}

Vegetables are those herbaceous plant whose parts or part are eaten as supporting food or main dish, it may be aromatic, bitter or tasteless (Ezekwe et al. 2013). They provide a source of food often low in cholesterols, saturated fat and dry matter content and are often consumed in addition to starchy food in order to make them more palatable (Ilodibia et al. 2016a). They are universally recognized to have great nutritional and medicinal values and form an essential part of a balanced human diet.

Talinum triangulare, a non - conventional vegetable belonging to the family Portulacaceae, is an erect fleshy perennial herb up to $60 \mathrm{~cm}$ high and is weed of cultivated field (Akobundu and Agyakwa 1998). It plays an important part in the diet of people in the tropics. The stem is succulent with either white or purple colour. Water leaf as a vegetable has some inherent characteristics which makes it attractive to small - holder farmers and consumers. This is because, it is a short duration crop which is due for harvest between $35-45$ days after planting (Rice et al. 1986). It is used as a softener when cooking fibrous vegetables such as afang (Gnetum africanum) and fluted pumpkin (Telferia occidentalis). Ibewuchi et al. (2007) noted that the leaves and young shoots are used to thicken sauce and is consumed in large quantities in the Southern part of Nigeria. Talinum triangulare is used in herbal medicine for the treatment of measles in Cameroon (Simo 1999, Chibill 1999), and as a tonic and fodder for raising plant snails in Indonesia (Rifai 1993) and to soothe inflammation in the South western Nigeria (Sofowara 1993). It has also been found to possess useful potentials such as laxative, purgative, treatment of diarrhea, gastro-intestinal disorders as well as in the management of cardiovascular diseases such as stroke and obesity (Ezekwe et al. 2001). These medicinal properties can only be possible as a result of the bioactive compounds present in this plant. However, there are some plants that have toxic constituents that are considered harmful to human. Although Talinum triangulare has been reported to be used extensively as food and medicine in some countries, yet there is need to investigate its various parts (leaf, stem and root) for phytochemical and nutritional potentials with the view of ascertaining their usefulness as drug and food as well as determine whether it has any poisonous compounds.

\section{Materials and methods}

\subsection{Area of study}

The experiments were carried out at the different laboratories of Plant Science and Biotechnology Department, University of Nigeria, Nsukka.

\subsection{Collection of plant samples}

The plant samples were collected between March-April 2015 from Agu-ukwu, in Anaocha Local Government Area, Anambra State. The Talinum species was authenticated at Department of Botany, NnamdiAzikiwe University, Awka where the voucher specimen was deposited.

\subsection{Materials used for proximate study}


The following materials were used in the proximate analysis: Dessicator, muffle furnace, spectrometer, silica dish, kjeldahl flask, funnel, soxhlet apparatus, filter paper, thimble, electric oven, grinder, retort stand, test tube and test tube rack, crucible, weighing balance, petri dish. The chemicals used include: Tetrahydrosulphate (vi) acid, Boric acid indicator solution, Sodium hydroxide, Hydrochloric acid, Petroleum ether, Potassium hydroxide, Acetone, Phenolphthalein indicator, Ammonia, Dithezone solution, Carbon tetrachloride, Hydroquinoline, Phenonthroline, VanadoMolybidic acid, Selenium oxide.

\subsection{Materials used for phytochemical study}

The materials and instruments used included plant specimen, blender (grinder), masking tape, mortar and pestle, moisture cans, crucibles, Whatman filter paper No 42, burettes, volumetric flasks, beakers, conical flasks, sample tubes, desiccators, spectrophotometer, muslin cloth, oven, measuring cylinder, spatula, electric scale, Bunsen burner(stove), funnels, aluminium foils, test tubes, syringes, pipettes, cotton wools, etc.

\subsection{Chemical and reagents used}

Ethanol (alcohols), concentrated acetic acid, sulphuric acid, diluted ammonia, water, ferric chloride, potassium ferrocyanide, ethyl acetate, hydrochloric acid, petroleum ether, sodium hydroxide, potassium hydroxide (potassium permanganate). Hydrogen peroxide, sodium chloride, copper sulphate, sodium picarate, methyl red, cresol green, folin-ciocaltean reagent, folin-dennis reagent, Erichrome black and solechrome dark blue

\subsection{Preparation of plant samples}

The leaf, stem and root of Talinum triangulare were cut into bits with a knife and oven dried at $70^{\circ} \mathrm{C}$ for $12 \mathrm{~h}$ to remove all moisture. The samples were then ground into fine powder.

\subsection{Extraction of plant material}

The ethanol extract of the plant was prepared by soaking $10 \mathrm{~g}$ of the ground sample of leaf, stem and root in $100 \mathrm{ml}$ of ethanol. The experimental set-up was left for $24 \mathrm{~h}$ at room temperature and thereafter filtered using Whatman No 1 filter paper. The extract was then concentrated to $50 \mathrm{ml}$ of the original volume of the extract and stored in an airtight container in a refrigerator at $4^{0} \mathrm{C}$ until when needed.

\subsection{Preliminary phytochemical screening}

Qualitative phytochemical screening of the extracts was conducted to determine the presence of these phytochemicals: tannin, saponin, flavonoid, alkaloid, sterol, phenol and cyanogenic glycoside. This was done using standard procedure as described by Harborne (1973).

Quantitative phytochemical test of the extracts was conducted to determine the percent quantitative contents of above phytochemicals using standard procedures described by Harborne (1973) and Pearson (1976).

Proximate (carbohydrate, ash, crude protein, dry matter, crude fibre, ether extract and moisture) contents were carried out to ascertain the nutrient compositions present in the plant extracts. Moisture content, total ash and protein were determined according to the method of AOAC (1990). Ether extract, dry matter and carbohydrate were determined using the method of James (1995) while crude fibre was done by solvent extraction gravimetric method described by Kirk and Sawyer (1998).

\subsection{Statistical analysis}

Results were presented in mean \pm standard deviation and were subjected to analysis of variance (ANOVA) using Duncan's Mul- tiple Range Test (DMRT) at 5\% probability to separate the treatments. Difference in mean value were considered significant at $\mathrm{P}<.05$.

\section{Results and discussion}

The results of the study were shown in Tables 1- 3 and Figure 1 Result revealed that some phytochemicals were absent from some parts of Talinum triangulare investigated. Alkaloid, flavonoid, tannin and saponin were present in all the parts tested. Sterol was lacking in the root, phenol was lacking in the root and stem while cyanogenic glycoside was absent from the leaf, root and stem (Table 1). Result showed also varying quantities of the phytochemicals in the leaf, stem and root with some parts lacking the phytochemicals (Table 2). The leaf contained the highest percentage of all the phytochemical investigated alkaloid, flavonoid, tannin, sterol, Terpenoid, phenol and saponin $(0.47 \pm 0.01,0.26 \pm 0.00$, $0.36 \pm 0.07,0.03 \pm 0.01,0.42 \pm 0.02,0.02 \pm 0.01$ and $0.68 \pm 0.05$ respectively (Table 2). The root lacked sterol and phenol while stem lacked only phenol. The leaf, stem and root lacked cyanogenic glycoside (Table 2). These phytochemicals were reported to be responsible for many antimicrobial activities of different plant species (Ghoshal et al. 1996, Iwu et al. 1999). Pharmaceutical and therapeutic values of plants and their products lie on the presence of these phytochemicals in them (Edeoga et al. 2005, Bishnu et al. 2009). Alkaloids are structurally diverse and are derived from different amino acids or mevalonic acids by various biosynthetic pathways (Robinson, 1981). They have an intensively bitter taste and many are extremely poisonous (Dutta 2004). The amazing effect of these alkaloids on human has led to the development of pain -killer medication, spiritual drugs and serious additions by those who are ignorant of the properties of the powerful chemical (Harborne et al. 1973). They are physiologically active in animals, usually even at very low concentrations, and many are widely used in medicine (e.g., cocaine, morphine, atropine, colchicines, quinine, and strychnine). Saponins are glycosides with distinctive foaming characteristics (Judd et al. 1999). They are natural detergents found in many plants (Ajali 2004). Saponins have both antibacterial and antifungal properties and are used extensively in cosmetics, such as lipsticks and shampoo. Flavonoids have been reported to be synthesized by plants in response to microbial infections and are good antibacterial agents. Tannins have been demonstrated to have antibacterial activities (Akiyama et al. 2001). Steroids are large group of naturally occurring and synthetic lipids, or fat soluble chemicals, with a great diversity of physiological activity synthetic steroids are well known for their use by athletes as a performance enhancing drug (Rossiers 2006).

Result revealed also that the nutrients were presents in all part of the Talinum triangulare investigated but in varied amount (Table $3)$. Dry matter and carbohydrate were highest in the stem $(91.69 \pm 0.12$ and $68.66 \pm 0.01)$ respectively. Moisture, ash content and crude fibre were highest in the root $(9.78 \pm 0.04$, $17.53 \pm 0.11$ and $15.32 \pm 0.03$ ) respectively while ether extract and crude protein were highest in the leaf $(1.09 \pm 0.01$ and $17.72 \pm 0.17)$ respectively (Table 3 ). The result has indicated that these parts are a good source of nutrients investigated which could be exploited in diet. The result has shown the stem to be a better source of dry matter and carbohydrate, the root a better source of moisture, ash content and crude fibre and the leaf a better source of ether extract and crude protein. These nutrients provide energy for work and warmth, provide materials for growth and repairs of worn out tissues, aid excretion and keep the organism healthy so that it can fight against diseases (Ilodibia et al. 2016a). The result is in line with the work of Ilodibia et al. (2016 b, c) who reported similar results among the various parts of Celosia argentea and Gomphrena celosioides. 
Table 1: Qualitative Phytochemical Composition of the Leaf, Stem and Root of Talinum triangulare

\begin{tabular}{llllllll}
\hline $\begin{array}{l}\text { Plant } \\
\text { Part }\end{array}$ & Alkaloid & Flavonoid & Tannin & Sterol & Terpenoid & Phenol & $\begin{array}{l}\text { Saponin } \\
\text { glycoside }\end{array}$ \\
\hline Leaf & + & + & + & + & + & + & + \\
Stem & + & + & + & + & + & + & + \\
Root & + & + & + & + & + & + \\
\hline
\end{tabular}

Key: Positive $(+\mathrm{ve})=$ presence.

Negative $(-\mathrm{ve})=$ absence

Table 2: Percent Quantitative Phytochemical Compositions of the Leaf, Stem and Root of Talinum triangulare (\%)

\begin{tabular}{llllllll}
\hline $\begin{array}{l}\text { Plant } \\
\text { parts }\end{array}$ & alkaloid & flavonoid & tannin & sterol & terpenoid & phenol & $\begin{array}{l}\text { Cyanogenic } \\
\text { glycoside }\end{array}$ \\
\hline Leaf & $0.47 \pm 0.01$ & $0.26 \pm 0.00$ & $0.36 \pm 0.07$ & $0.03 \pm 0.01$ & $0.42 \pm 0.02$ & $0.02 \pm 0.00$ & $0.68 \pm 0.05$ \\
Stem & $0.29 \pm 0.01$ & $0.22 \pm 0.02$ & $0.17 \pm 0.00$ & $0.01 \pm 0.00$ & $0.25 \pm 0.02$ & - & - \\
Root & $0.22 \pm 0.01$ & $0.16 \pm 0.00$ & $0.32 \pm 0.03$ & - & $0.19 \pm 0.00$ & - & - \\
\hline
\end{tabular}

Results are in mean \pm standard deviation. Columns followed by the same letter are not significantly different at $\mathrm{p}<.05$.

Table 3: Percent Proximate Compositions of the Leaf, Stem and Root of Talinum Triangulare (\%)

\begin{tabular}{lllllll}
\hline $\begin{array}{l}\text { Plant } \\
\text { parts }\end{array}$ & dry matter & CHO & moisture & ash & fibre & Ether \\
\hline Leaf & $90.48 \pm 0.04$ & $47.56 \pm 0.00$ & $9.53 \pm 0.11$ & $13.80 \pm 0.01$ & $14.83 \pm 0.02$ & $1.09 \pm 0.01$ \\
Stem & $91.69 \pm 0.12$ & $68.66 \pm 0.01$ & $8.32 \pm 0.00$ & $6.49 \pm 0.00$ & $12.29 \pm 0.02$ & $0.25 \pm 0.00$ \\
Root & $90.23 \pm 0.01$ & $50.16 \pm 0.00$ & $9.78 \pm 0.04$ & $17.53 \pm 0.11$ & $15.32 \pm 0.03$ & $0.18 \pm 0.00$ \\
\hline
\end{tabular}

Results are in mean \pm standard deviation. Columns followed by the same letter are not significantly different at $\mathrm{p}<.05$.

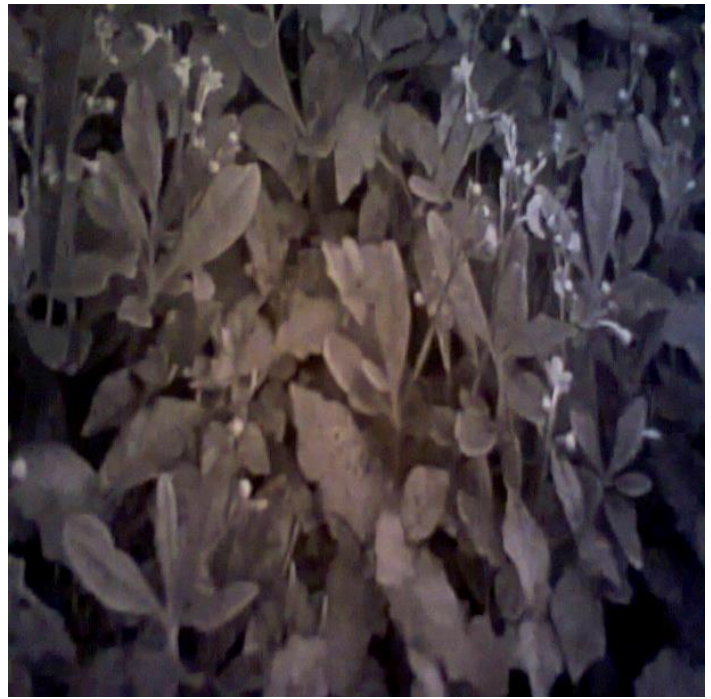

Fig. 1: Talinum triangulare

Plant Source: Self Collection from Wild.

\section{Conclusions}

The results of the study revealed that these parts of the Talinum triangulare investigated are very nutritious and can contribute significantly to the human health requirements. This study revealed also that the plant extracts possessed bioactive compounds that could be extracted for the manufacture of new drug, food supplements and be used in ethnomedicine for the treatment of diseases.

\section{References}

[1] Ajali U (2004) Chemistry of Biocompounds, $1^{\text {st }}$ ed. Rhyce Kerex Publishers. Enugu, Nigeria.

[2] Akiyama H, Fujii K, Yamasaki O, Oono T, Iwatsuki K (2001) Antibacterial Action of Several Tannins against Staphylococcus aure us. Journal of Antimicrobial Chemotherapy 48(4):487-491.

[3] Akobundu IO, Agyakwa CW (1998) A Hand Book of West African Weeds. International Institute for Tropical Agriculture.565pp.

[4] AOAC (1990) Official Method of Analytical Chemistry, Washing ton DC. 235PP Bishnu JU, Sunil L, Anuja S (2009) Antibacterial Properties of different Medicinal Plants; Ocimum sanctum, Cin- namomum zeylanicum, Xanthoxylim arimatum and Origanum masorana. Kathmandu Univer. J. Sci Engineer Tech 5: 143-150.

[5] Chibill EO (1999) A comparative study of some development characteristics in Talinum fructicosum (L) Juss. Accessions from stem cutting in Dschang. Memoire de Matrise Universitede Dschang 37pp.

[6] Dutta AC (2004) Botany for Degree Student (5 ${ }^{\text {th }}$ edition), Oxford University Press, London.708pp.

[7] Edeoga HO, Okwu DE, Mbaebie BO (2005) Phytochemical Constituents of some Nigerian Medicinal Plants. African Journal of Biotechnology 4: 685 - 688. https://doi.org/10.5897/AJB2005.0003127.

[8] Ezekwe MO, Besong SA, Igbokwe PE (2001) Beneficial Influence of Purslane and Waterleaf Supplement to Humans, FASEB Journal, 16: A633393.

[9] Ghoshal SK, Prasad BN, Lakshmi V (1996) Antiamoebic Activity of Piper longum Fruits against Entamoeba histolytica In Vitro and

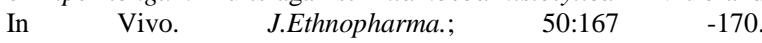
https://doi.org/10.1016/0378-8741(96)01382-7.

[10] Harborne JB (1973) Phytochemical Methods: A Guide to Modern Techniques in Plant Analysis. Chapman and itzl Press, New York, 660pp.

[11] Ibeawuchi II, Nwufo MI, Oti NN, Opara CC, Eshett ET (2007) Productivity of Intercropped Green (Amaranthus cruentus) waterleaf Talinum triangulare with poultry manure rates in southern $\mathrm{Ni}$ - 
geria. Journal of Plant Sciences, 2(2): 222-227. https://doi.org/10.3923/jps.2007.222.227.

[12] Ilodibia CV, Chukwu AJ, Akachukwu EE, Adimonyemma RN, Igboabuchi NA, Okeke NF (2016a) Proximate, Phytochemical and Antimicrobial Studies on Solanum Macrocarpon L. Journal of Advances in Biology and Biotechnology; 9 (2): 1-7 https://doi.org/10.9734/JABB/2016/27922.

[13] Ilodibia CV, Ewere FU, Akachukwu EE, Adimonyemma RN, Igboabuchi NA, Okeke NF (2016b) Proximate Composition, Vitamin and Anatomical Studies on Gomphrena celosioides. Annual Research \& Review in Biology; 10 (3) 1-6. https://doi.org/10.9734/ARRB/2016/25546.

[14] Ilodibia CV, Chukwuka C, Akachukwu EE, Adimonyemma RN, Igboabuchi NA, Chukwuma MU (2016c) Anatomical, Proximate, Mineral and Vitamin Studies on Celosia argentea (Linn) British
Biotechnology
Journal;
(4)
$1-7$. https://doi.org/10.9734/BBJ/2016/28300.

[15] Iwu MW, Duncan AR, Okunji CO (1999) New Antimicrobials of Plant Origin. In: J. Janic $2^{\text {nd }}$ edn, Perspective on New Crops and new Uses. Asits Press, Alexandria.

[16] James CS (1995) Analytical Chemistry of Foods. Chapman and Hall, New York, 53pp. https://doi.org/10.1007/978-1-4615-2165-5.

[17] Judd WS, Campbell CS, Kellogg EA, Stevens PE (1999) Plant Systematics; A Phylogenetic Approach. Sinauer Associates Inc. Sunderland, Massachusetts U. S. A, PP.208- 305.

[18] Kirk H, Sawyer R (1998) Frait Pearson Chemical Analysis of Food $\left(8^{\text {th }}\right.$ ed). Longman Scientific and Technical, Edinburgh. 211-212pp.

[19] Pearson D (1976) Chemical Analysis of Foods. Churchill Livingstone, Edinburgh, 7-14pp.

[20] Rice RP, Rice IW, Tindau HD (1986) Fruits and Vegetables in the Tropics. Macmillian Publishers Ltd. London 200-202pp.

[21] Rifai M A (1995) Talinum triangulare (Jacq) Wild. In: Siemonsma J.S., and Kasen P. (Eds). Plant Resources of south- east Asia number 8 vegetables. Pudoc Scientific Publishers, Wageningen, Netherlands, 319pp.

[22] Robinson T (1981) the Biotechnology of Alkaloids, $2^{\text {nd }}$ ed. Springer Verlag, New York. 250pp.

[23] Rosier MF (2006) T-channels and Steroid Biosynthesis Search of a link with Mitichodria. Cell Calcium 40(2):155-164. https://doi.org/10.1016/j.ceca.2006.04.020.

[24] Simo C (1999) Caracteristiques Morphologiqqqques et usages du grasse. Talinum fructicosum (L) Juss. Portulaceae au Cameroon. Memoire de Matrise Universite de Dschang 31pp.

[25] Sofowora A (1993) Medicinal Plants and Traditional Medicine in Africa. Spectrums Books ltd, Ibadan, Nigeria. 289pp. 